From the Department of Microbiology and Immunology, Norwegian College of Veterinary Medicine, Oslo, Momarken Equine Clinic, Mysen, and Laboratory of Entomology, National Institute of Public Health, Oslo, Norway.

\title{
Intradermal Challenge of Icelandic Horses in Norway and Iceland with Extracts of Culicoides spp.
}

\author{
By Hans Jørgen Larsen, Svein Halvard Bakke and Reidar Mehl
}

\begin{abstract}
Larsen, H. J., S. H. Bakke and R. Mehl: Intradermal challenge of Icelandic horses in Norway and Iceland with extracts of Culicoides spp. Acta vet. scand. 1988, 29, 311-314. - A skin test survey was carried out in Icelandic horses in Norway and Iceland using extracts of Culicoides spp. as antigen. Eleven horses with recurrent seasonal dermatitis reacted with an immediate hypersensitivity response to intradermal challenge with antigen. All except one of thirty-three clinically normal horses in Norway showed a negative response in skin tests. These findings indicate that Culicoides spp. may be the major cause of the disease in Norway. Only one of the 110 horses tested in Iceland showed any skin test reaction (weak), demonstrating that the horses were not sensitized to Culicoides allergen. The disease has never been reported in Iceland.
\end{abstract}

allergic dermatitis; sweet itch; skin test reaction.

\section{Introduction}

A recurrent seasonal dermatitis of horses, characterised by intense pruritus with a distribution on the dorsal and ventral part of the body, is often seen in horses. This condition occurs worldwide, and is referred to by different local names. In Great Britain and Ireland, the term "sweet itch" is issued to describe the condition, which has been attributed to a hypersensitive reaction to biting insects (Riek 1955, Mellor \& McCraig 1974). In Norway, a similar superficial dermatitis occurring in Icelandic horses is called "summer eczema" (SE).

The present study describes the reaction of clinically normal horses and of animals with SE in Norway, to extract of antigens from Culicoides spp. following intradermal challenge. A skin test survey was also carried out on horses in Iceland.

\section{Materials and methods}

\section{Animals}

Thirty-three clinically normal Icelandic horses and 11 Icelandic horses with typical lesions of "summer eczema" (SE) in Norway, and 110 horses without signs of eczema in Iceland, were challenged intradermally with extracts of Culicoides spp. as described below. The age of the horses varied between 4 and 16 years. Two Icelandic horses affected with SE born in Norway were also tested.

\section{Extract of Culicoides spp.}

Biting midges belonging to the genus Culicoides were collected in the south east region of Norway and used for antigen preparation without separating into species. The Culicoides extract was prepared as a 1 per cent $\mathrm{w} / \mathrm{v}$ saline solution following grinding and filter sterilisation. The dominating species 
on the collection site were Culicoides obsoletus, Culicoides chiopterus and Culicoides impunctatus.

\section{Intradermal tests}

On an area on the neck of each horse the coat was shorn very close to the skin. A volume of $0.1 \mathrm{ml}$ of antigen extract $(0.01 \mathrm{per}$ cent) was injected intradermally using a 25 gauge needle. Histamine base $(0.1 \mathrm{mg}$ per $\mathrm{ml}$ ) and sterile saline solution were used as controls. Reactions were recorded as the mean wheal diameter of two perpendicular measurements made $30-60 \mathrm{~min}$. following injection. A skin reaction to antigen was considered to be positive when the wheal response was at leat $3 \mathrm{~mm}$ greater than that of the saline control.

\section{Results}

The effect of different antigen concentrations on the skin reaction was tested in 4 horses with recurrent seasonal eczema (Table 1). All horses responded to antigen when diluted up to 1:100, and two horses showed a positive reaction to antigen diluted 1:10000. A 0.01 per cent concentration of antigen was chosen as the working dilution in the following study.

Altogether 154 Icelandic horses were intradermally challenged with antigen. Of these,

Table 1. Increases in skin reaction $(\mathrm{mm})$ in horses with "summer eczema" after intradermal challenge with Culicoides spp. extract in different dilutions.

\begin{tabular}{lrrrrr}
\hline & \multicolumn{5}{c}{ Dilution of antigen } \\
\cline { 2 - 6 } Horse & $10^{*}$ & $10^{-1}$ & $10^{-2}$ & $10^{-3}$ & $10^{-4}$ \\
\hline 1 & 7.5 & 8 & 6.5 & 5 & 3.5 \\
2 & 10 & 12 & 11 & 11 & 11 \\
3 & ND & ND & 5.2 & 2 & 2.5 \\
4 & ND & 7 & 4 & 4 & ND \\
\hline
\end{tabular}

$\mathrm{ND}=$ not done.
Table 2. The prevalence of positive skin reactions to Culicoides spp. antigen in horses with or without "summer eczema" (SE) in Norway and in Iceland.

\begin{tabular}{lcc}
\hline & \multicolumn{2}{c}{$\begin{array}{c}\text { Animals with positive skin reaction/ } \\
\text { total number of animal tested }\end{array}$} \\
\cline { 2 - 3 } & $\begin{array}{c}\text { horses with } \\
\text { clinical SE }\end{array}$ & $\begin{array}{c}\text { horses without } \\
\text { SE }\end{array}$ \\
\hline Imported horses & $11 / 11$ & $1 / 33$ \\
Horses in Iceland & - & $1 / 110$ \\
\hline
\end{tabular}

44 were in Norway, having been imported from Iceland, and 110 were in Iceland. All imported horses with clinical SE showed a positive skin reaction, whereas only one of the thirty-three horses with no signs of the disease was positive (Table 2). This horse had in fact been born a few months after the dam had arrived in Norway. Only one of the 110 horses tested in Iceland responded positively to the skin test, the reaction being weak ( $3 \mathrm{~mm}$ increase). Clinical SE has never been reported in Iceland.

Two icelandic horses with SE born in Norway were also tested. They responded with a positive skin reaction (not shown in Table 2 ). The mothers of both these animals exhibited severe signs of $\mathrm{SE}$ as well as positive skin reactions to Culicoides antigen.

\section{Discussion}

This study showed that horses with clinical SE reacted to intradermal challenge with extract from Culicoides spp. All but one of the Icelandic horses in Norway without SE failed to respond in skin tests. The exceptional animal was born shortly after the importation of the mare, which had severe SE. The offspring was probably in the process of developing the condition. A skin test survey carried out in horses from different parts of Iceland demonstrated that they were not sensitized to Culicoides allergen. 
It has been suggested that the condition is due to allergy to biting insects. Several species of the genus Culicoides are considered capable of inducing a hypersensitivity reaction; Culicoides pulicaris (Mellor \& McCaig 1974), Culicoides brevitarsis (Riek 1955), Culicoides punctatus, C. nubeculosus and C. pulicaris (Townley et al. 1984), and C. imicola and C. circumscriptus (Braverman et al. 1983). In some of the mentioned studies, no differentiation into Culicoides species was carried out before preparation of extracts for intradermal challenge (Baker \& Quinn 1978, Quinn et al. 1983). The response of horses with SE to the undifferentiated Culicoides spp. antigen used in the present investigation, indicates that Culicoides hypersensitivity may be the major cause of the disease also in Norway.

Clinical disease has never been reported in Iceland, and there is no record of any Culicoides species (Illies 1978). The fact that Culicoides species are not found in Iceland is supported by the described skin test survey carried out in Iceland. However, when horses are exported to countries with other climatic conditions, some will show disease. One important observation made by horse owners and veterinarians in Norway is that Icelandic horses born in Norway seldom develop SE, in contrast to those that are imported. Though responses to a questionnaire sent to a limited number of horse owners support this observation (Larsen \& Bakke 1983, unpublished), we feel that there is a need to carry out more compretensive epidemiological investigations to obtain further evidence to verify this observation. One explanation may be that maternal antibodies protect the foal against developing a hypersensitivity reaction. Horses which are sensitized during the first 2 to 3 summer seasons will produce both IgE and IgG antibodies against the insect antigen. If they pro- duce mainly IgE, they may develop SE. The horses that have mainly IgG will not show SE. After parturition, IgG antibodies will be transferred from the mare to the foal, and these will interfere with the sensitizing antigen, inducing production of $\mathrm{IgG}$ instead of IgE. The foal will not show clinical signs. However, when the mare has produced very little IgG, the foal will show SE. This could be the situation for the two horses with SE in the present study, as both had mothers with severe SE. The hypothesis of protective maternal antibodies is supported by the observation that the foal born shortly after importation of the mare developed a positive skin reaction. As the mare had not been sensitized before parturition, no antigen specific $\mathrm{IgG}$ antibodies would have been transferred to the foal.

In Norway the foals are born during late winter and spring. The protective role of maternal antibodies may, however, be of minor importance for horses born early in periods of low insect activity (October-March) as the antibodies probably will be metabolized before the animals are exposed to antigens (April-September).

The ability to develop a hypersensitivity reaction to biting insects may be inherited. As susceptibility to the disease may be based on special specific immune reactions to antigen, one could expect a disease association to MHC (Major histocompatibility complex)-products in horses. This hypothesis was investigated by typing about 160 Icelandic horses, with or without SE, in Switzerland and in Norway, for serologically detectable horse leucocyte (ELA) antigens (Lazary et al. 1982). In Norway the prevalence of animals positive to certain specific antigens was significantly higher in horses suffering from summer eczema than in those that were clinically healthy. If these preliminary findings were to be comfirmed in a study 
comprising a large number of horses, one could consider typing horses in Iceland before exportation in order to exclude those that were subsequently liable to develop the disease abroad.

\section{Acknowledgements}

Thanks are due to Miss Bente Becker Johansen for excellent technical assistance. The study was supported by a grant from the Agricultural Research Council of Norway.

\section{References}

Baker KP, Quinn PJ: A report on clinical aspects and histopathology of sweet itch. Equine Vet. J. 1978, 10, 243-248.

Braverman $Y$, Ungar-Waron $H$, Frith $K$, Adler $H$, Danieli $Y$, Baker KP, Quinn PJ: Epidemiological studies of sweet itch in horses in Israel. Vet. R. 1983, 112, 521-524.

Illies J: Limnofanuna. Europaea. Gustav Fisher Verlag, Stuttgart, New York 1978, p. 532.

Lazary S, Larsen HJ, Glatt A, Isenbügel E, Gerber H: Distribution of ELA antigens in "sweet itch" of horses. XVIIIth International Conference on Animal Bloodgroups and Biochemical Polymorphisms. Ottawa, Canada, 18.24. July 1982 Abstract p. 67.

Mellor PS, Mc Caig J: The probable cause of "sweet itch" in England. Vet. Rec. 1974, 95 , 411-415.
Quinn PJ, Baker KP, Morrow AN: Sweet itch: Responses of clinically normal and affected horses to intradermal challenge with extracts of biting insects. Equine Vet. J. 1983, 15, 266-272.

Riek $R F$ : Studies on allergic dermatitis (Queensland itch) of the horse: The aetiology of the disease. Austr. J. Agricult. Res. 1955, 5, 109129.

Townley K, Baker KP, Quinn PJ: Preferential landing and engoring sites of Culicoides species landing on a horse in Iceland. Equine Vet. J. 1984, 16, 117-120.

\section{Sammendrag \\ Intracutan testing av islandshester $i$ Norge og på Island med ekstrakter av Culicoides spp. \\ Intracutan testing av islandshester i Norge og på Island ble utført med ekstrakt fra Culicoides spp. som antigen. Elleve norske hester med sommer- eksem (SE) reagerte med en "straks-allergisk" reaksjon på intrakutan inokulasjon med antigen, mens trettito af trettitre hester uten SE ikke rea- gerte. Dette indikerer at Culicoides spp. allergen er hovedårsaken til sykdommen også i Norge. Bare en av hundre og ti hester på Island reagerte, og responsen var svak. Dette viser at hester på Island ikke er sensitert med Culicoides antigen. Sykdommen har aldri vært rapportert på Island.}

(Received January 4, 1988).

Reprints may be requested from: H. J. Larsen, Norwegian College of Veterinary Medicine, Department of Microbiology and Immunology, P.O. Box 8146, Dep., N-0033 Oslo 1, Norway. 